\title{
1. The EU and the promotion of renewable energy: an analytical framework
}

\section{Helge Jörgens and Israel Solorio}

\subsection{WHY THE EU RENEWABLE ENERGY POLICY?}

There are several reasons why the promotion of renewable energy sources (RES) has ranked high among the priorities of the European Union (EU) in the field of energy policy, including a broad range of political, economic and environmental factors. Yet perhaps the single most important reason why the EU has become a global forerunner in the promotion of RES relates to the EU's institutional structure and the resulting nature of its energy policy. On the one hand, since a formal competence in the field of energy policy was not given to the EU until the Treaty of Lisbon in 2009 (Morata and Solorio, 2012), for years the European "policy-makers borrowed legal competence from economic and environmental parts of the EU treaties in order to justify proposing and passing energy measures' (Buchan, 2009, p. 7). In particular, environmental policymaking provided an effective basis for EU programmes and policies in the field of energy policy and a potent channel for increasing the EU's influence on the energy policies of its member states (Tosun and Solorio, 2011). Against this backdrop, RES promotion, together with the promotion of energy efficiency and savings, was an almost natural choice for the EU in order to increase its overall influence in the energy policy field (Morata and Solorio, 2012). On the other hand, since the 1970s, the idea of a 'Green Europe' has gradually turned into one of the normative foundations of the EU (Lenschow and Sprungk, 2010, p. 134). A recent expression of the EU's self-perception as an ecological forerunner is its aspiration to become a global leader in climate change policy (Wurzel and Connelly, 2011). Within this strategy, RES promotion became a flagship component of the EU's energy policy (Knudsen, 2012). 
Today, RES promotion continues the important role that energy issues have played throughout the historical process of European integration. However, while the European Coal and Steel Community (ECSC) in 1951 and the European Atomic Energy Community (Euratom) in 1957 were both founding pillars of what is nowadays known as the EU (Matláry, 1997, p. 14), today none of these institutions constitute core elements of the EU's energy policy. The ECSC expired in 2002, whereas Euratom remains as a 'separate legal entity' from that of the European Union (Barnes, 2013, p. 106). Conversely, RES promotion appeared on the agenda back in the 1970s together with efforts of the European Commission to invigorate cooperation in the energy field after the oil crisis (see Chapter 2 by Solorio and Bocquillon on the history of EU renewable energy policy). Ever since then, it has figured prominently on the EU's policy agenda.

But RES promotion, as well as energy policy as a whole, has become increasingly politicized in the EU over the past years (Tosun et al., 2015). In an EU obsessed with recovering the vigour and competitiveness of its economy, RES promotion is persistently being contested, both at the European level and within the member states. The October 2014 European Council's discussions on the climate and energy targets for 2030 were illustrative of this turn. While during the negotiations of the 2009 climate and energy package there was a broad consensus among member states on the need of having binding national targets for RES promotion for 2020, this time the agreement was reduced to a global RES target for the EU as a whole (see Chapter 2 by Solorio and Bocquillon). The EU is generally considered as a world leader on RES promotion. However, for many critics, recent developments concerning the 2030 goals place this position at risk, together with the European 'greenness' (see the Foreword by Hinrichs-Rahlwes).

This book proposes to be a guide for understanding the EU renewable energy policy, understood as the set of policy instruments developed at the European level to promote RES between the member states, including instruments of regional policy, research and development programmes, and market and environmental measures. In particular, we are interested in shedding light on the complex interplay of domestic and European drivers of policy change in the promotion of RES in the fields of electricity (RES-E) and transport (biofuels). ${ }^{1}$ How do actors, institutions and policies at the supranational, national and local level affect each other, resulting in a European multi-level regime for the promotion of RES? What role do processes of top-down, bottom-up and horizontal Europeanization play, and how do they interact? Although the policies of RES promotion in the EU have received considerable attention in the 
literature, in particular by scholars in the fields of European studies, environmental policy and energy policy (e.g. Mez, 2007; Jacobs, 2012; Boasson and Wettestad, 2013), we still lack a thorough understanding of the interplay of policymaking at the European level and in the member states (or even the countries in the EU's neighbourhood).

Against this backdrop, the objective of this book is to present a detailed and updated picture of what the EU renewable energy policy is, how it evolved, and how it interacts with the domestic policies of its member states. The book compares the development of RES policies in ten EU member states (Bulgaria, Denmark, France, Germany, Italy, the Netherlands, Poland, Romania, Spain, and the United Kingdom) as well as in selected non-EU countries, and explores how they interact with RES policymaking at the EU level. We apply a common analytical framework that draws on the Europeanization literature as well as on concepts and findings from the literature on policy diffusion, thereby following the 'European' route to the study of national politics and policies (Vink and Graziano, 2007, p. 4). Focusing on the whole EU policy cycle, the chapters in this book aim to understand how member states have shaped the EU's renewable energy policy, how EU policies have affected policymaking at the national level, how policies and instruments adopted at the national level have diffused between member states, and how and why the positions of the member states towards an EU-wide harmonization of renewable energy policies have changed over time. This picture is completed by an analysis of the external dimension of the EU renewable energy policy, for both RES-E and biofuels. In sum, this book aims to provide a comprehensive and multifaceted understanding of the EU renewable energy policy as one of the longest and most ambitious attempts worldwide to facilitate the transition towards a more sustainable energy system.

\subsection{RENEWABLE ENERGY AND THE EUROPEANIZATION OF ENERGY POLICY}

In order to study renewable energy policy in the EU and to untangle the complex policy process that surrounds it, we draw on the Europeanization framework as our principal analytical tool. Adopting a Europeanization perspective allows us to put emphasis not only on the domestic drivers of national policy change, but also on the (sometimes neglected) role of the EU in RES promotion. It also directs our analytical focus to the 'interactive process' of EU policy-making (Radaelli, 2004), characterized by an interdependent mix of uploading, downloading and 
cross-loading of policies and programmes between the European and the national levels and across EU member states (Bulmer and Radaelli, 2004; Bache and Jordan, 2006). In order to adequately account for the multiplicity of factors that drive policy change in the European multilevel polity, we distinguish between three types of Europeanization bottom-up, top-down and horizontal - all of which prove to be relevant in some countries or at some point in time. Thus, by adding a horizontal dimension, our analytical framework goes beyond concepts of Europeanization as a 'two-way process' where 'member state governments both shape European policy outcomes [bottom-up] and adapt to them [top-down]' (Börzel, 2002, pp. 193-194). Horizontal Europeanization that is, the direct diffusion or transfer of policies from one EU member state to another in the shadow of potential EU-wide harmonization - has received only marginal attention in the Europeanization literature (see, e.g., Bomberg and Peterson, 2000; Liefferink and Jordan, 2004). However, in the energy policy domain, where the EU has only limited competences, we argue that it might play an important role.

The following section presents in more detail the three forms of Europeanization and their relationship to the EU renewable energy policy, and integrates them into the analytical framework that will guide the empirical chapters of the book. Table 1.1 gives an overview of the different types of Europeanization and their underlying causal mechanisms, as well as their potential outcomes.

\subsubsection{Bottom-Up Europeanization}

Arguably, 'bottom-up' Europeanization is the point where the European policy cycle starts. It describes how policies or institutions are initially formed at the European level (Vink and Graziano, 2007, p. 9); how European norms, rules and practices evolve over time (Börzel, 2002, p. 193). Bottom-up Europeanization focuses on the influence of member states in the formulation of policies at the EU level (Radaelli, 2004). Member state governments are the single most important group of actors in the process of EU policymaking, either directly in the Council of Ministers or indirectly by setting the terms under which power is delegated to the supranational bodies of the EU. Thus, ultimately, it is the member states who decide whether to adopt new EU legislation or not. Accordingly, Bulmer and Radaelli (2004) refer to this kind of Europeanization as 'governance by negotiation', where the member state executives hold a key position in the decision-making process (Börzel, 2002, p. 195). 

Table 1.1 Types of Europeanization, causal mechanisms and expected
outcomes

\begin{tabular}{|c|c|c|c|}
\hline $\begin{array}{l}\text { Europeanization } \\
\text { type }\end{array}$ & Causal mechanisms & Sources of influence & $\begin{array}{l}\text { Expected } \\
\text { outcomes }\end{array}$ \\
\hline \multirow[t]{3}{*}{$\begin{array}{l}\text { Bottom-up } \\
\text { (uploading) }\end{array}$} & Pace-setting & $\begin{array}{l}\text { Strategic capacity for } \\
\text { pushing policies linked to } \\
\text { national preferences }\end{array}$ & \multirow{3}{*}{$\begin{array}{l}\text { Minimize the } \\
\text { costs or } \\
\text { maximize the } \\
\text { benefits of } \\
\text { EU policies }\end{array}$} \\
\hline & Foot-dragging & $\begin{array}{l}\text { Power for blocking or } \\
\text { weakening policies } \\
\text { potentially costly for } \\
\text { national interests or at least } \\
\text { obtaining side-payments }\end{array}$ & \\
\hline & Fence-sitting & $\begin{array}{l}\text { Neutral or indifferent } \\
\text { stance; building tactical } \\
\text { coalitions }\end{array}$ & \\
\hline \multirow[t]{3}{*}{$\begin{array}{l}\text { Top-down } \\
\text { (downloading) }\end{array}$} & $\begin{array}{l}\text { Prescription of } \\
\text { concrete } \\
\text { institutional and } \\
\text { governance models }\end{array}$ & $\begin{array}{l}\text { Degree of institutional } \\
\text { compatibility }\end{array}$ & \multirow{3}{*}{$\begin{array}{l}\text { Policy } \\
\text { change or } \\
\text { policy } \\
\text { resistance } \\
\text { derived from } \\
\text { the EU } \\
\text { impulse }\end{array}$} \\
\hline & $\begin{array}{l}\text { Altering the } \\
\text { opportunity } \\
\text { structure }\end{array}$ & $\begin{array}{l}\text { Resource and power } \\
\text { redistribution between } \\
\text { domestic actors }\end{array}$ & \\
\hline & $\begin{array}{l}\text { Promoting changes } \\
\text { in the beliefs and } \\
\text { expectations }\end{array}$ & $\begin{array}{l}\text { Mobilization of support for } \\
\text { domestic reforms }\end{array}$ & \\
\hline \multirow[t]{3}{*}{$\begin{array}{l}\text { Horizontal } \\
\text { (cross-loading) }\end{array}$} & Learning & $\begin{array}{l}\text { Availability and use of } \\
\text { information about existing } \\
\text { policies in other EU } \\
\text { member states (e.g., best } \\
\text { practice) }\end{array}$ & \multirow{3}{*}{$\begin{array}{l}\text { Cross-national } \\
\text { policy } \\
\text { convergence } \\
\text { in the absence } \\
\text { of EU-wide } \\
\text { legal } \\
\text { harmonization }\end{array}$} \\
\hline & $\begin{array}{l}\text { Norm-based } \\
\text { imitation }\end{array}$ & $\begin{array}{l}\text { Notions about appropriate } \\
\text { action in the field of RES } \\
\text { policy are shared across EU } \\
\text { member states; norm } \\
\text { entrepreneurs try to push } \\
\text { these ideals }\end{array}$ & \\
\hline & $\begin{array}{l}\text { Competition } \\
\text { (political or } \\
\text { economic) }\end{array}$ & $\begin{array}{l}\text { Governments take } \\
\text { unilateral action in order to } \\
\text { avoid or minimize negative } \\
\text { political or economic } \\
\text { externalities resulting from } \\
\text { other member states' } \\
\text { policies }\end{array}$ & \\
\hline
\end{tabular}

Sources: Based on Knill and Lehmkuhl (1999, 2002), Börzel (2002) and Busch and Jörgens (2012a). 
In processes of bottom-up Europeanization - or, as Börzel (2002) terms it, the 'uploading' of domestic policies and institutions to the EU level individual member states may become disproportionately influential in the formulation and adoption of EU policies. The mechanism of bottom-up Europeanization has been thoroughly explored in the literature on the role, influence and strategies of environmental forerunner states (Andersen and Liefferink, 1997; Liefferink and Andersen, 1998). In general terms, this literature on leaders (as well as laggards) assumes a rational behaviour on the part of the member states. For example, Börzel (2002) argues that member states' 'responses to Europeanization are shaped, firstly, by their policy preferences and, secondly, by their action capacities' (Börzel, 2002, p. 196). Specific focus has been placed on member states that take on the role of forerunners or pioneers. A forerunner can be defined "as a member state which is "ahead" of EU environmental policy in the sense of having developed more advanced policies' (Liefferink and Andersen, 1998, p. 256). Liefferink and Andersen consider that one of the main drivers for EU member states to become pioneers in environmental policymaking and subsequently try to upload their ambitious policies to the European level is to avoid competitive disadvantages for their industry (Liefferink and Andersen, 1998, p. 254).

An important attempt to identify the strategies used by environmental pioneers to shape policies at the EU level was made by Liefferink and Andersen (1998, p. 256), who distinguished the roles of pusher by example, defensive forerunner, constructive pusher and opt-outer. Building on this work, Börzel (2002) identified three typical ways in which member states responded to Europeanization. The first strategy, 'pacesetting', is about pushing those policies at the European level that reflect a member state's policy preferences in order to minimize the subsequent implementation costs. For some time, this strategy was used mainly by the classic 'green' member states (Germany, Denmark, the Netherlands, Sweden, Finland and Austria) (Liefferink and Andersen, 1998). The second strategy, 'foot-dragging', consists of blocking or delaying costly policies in an effort to prevent them altogether, or at least to achieve some compensation for the expected implementation costs. Blocking the adoption of stricter EU (environmental) law is often considered to be a 'southern problem' (Börzel, 2000). Finally, with less pronounced policy preferences, member states are likely to take a neutral stance in the European policy process. This third strategy is known as 'fence-sitting' and includes building tactical coalitions with both pace-setters and foot-draggers (Börzel, 2002). All in all, as Tosun et al. (2015) argue, the bottom-up perspective of Europeanization research provides a good 
explanation for how the EU policymakers' agendas are shaped, namely by (influential) member states and their respective preferences.

\subsubsection{Top-Down Europeanization}

While bottom-up Europeanization relates to the ways in which EU member states shape European policies, institutions and laws, top-down Europeanization relates to the implementation or the impact of these EU policies at the domestic level of the member states. Given that the adoption and implementation (or non-implementation) of EU directives is easily observable, top-down Europeanization occupies a central place in most of the Europeanization literature. This kind of Europeanization occurs where 'the supranational institutions have a considerable amount of power delegated to them' (Bulmer and Radaelli, 2004, p. 5), and it provides a useful analytical tool to study how Europe and the EU matter (Börzel and Risse, 2000). But, as Caporaso argues, the 'route from Brussels to member states is not a straight line' (Caporaso, 2007, p. 30) as 'the domestic outcomes feed back into the process of Europeanization' (Caporaso, 2007, p. 27). Therefore, in order to understand the domestic change produced by top-down Europeanization, it is necessary to understand how it interacts with a variety of domestic factors.

Knill and Lehmkuhl's (1999) typology of Europeanization mechanisms is a useful guide for understanding the variety of impulses generated by the EU from above. According to the authors, EU policies and programmes create adaptational pressures that span from: (1) the prescription of concrete institutional and governance models; to (2) altering opportunity structures at the domestic level; and (3) promoting changes in the beliefs and expectations of the domestic actors in order to gain support for the reforms promoted by the EU (Knill and Lehmkuhl, 1999, 2002). In this sense, it might be considered that very often a European directive includes more than one of these Europeanization mechanisms.

Most of the top-down Europeanization literature has emphasized the role of the prescription of concrete regulatory or institutional models. Here, the degree of fit or misfit between policies or institutions at the European level and those at the level of individual member states creates adaptational pressures which in turn affect the degree of domestic policy change (Risse et al., 2001, p. 7). Börzel and Risse (2000, p. 5) argue that 'adaptational pressures are generated by the fact that the emerging European polity encompasses structures of authoritative decision-making which might clash with national structures of policy-making'. In this case, whether change at the national level will occur depends on the existence of a prior misfit as the explanatory factor for policy change. 
However, empirical evidence suggests that European policies may lead to domestic policy change even in cases of 'complete congruence between European and domestic policy and institutional arrangements' (Knill and Lehmkuhl, 2002, pp. 256-257). Bulmer and Radaelli (2004, p. 9) contend that the misfit or 'goodness of fit' argument 'is valid only under certain conditions', namely, when there is a presence of EU policy templates or models. In fact, the EU renewable energy policy is a case where the misfit is practically non-existent because of a lack of a harmonized support scheme model (see Chapter 2 by Solorio and Bocquillon). Therefore, the challenge in this context is to investigate whether and how Europeanization can be possible even without the misfit element.

The second mechanism identified by Knill and Lehmkuhl, altering domestic opportunity structures, refers primarily to a change in the distribution of power and resources between actor coalitions caused by European policymaking (Knill and Lehmkuhl, 2002, p. 268). Europeanization challenges existing 'institutional equilibria' by strengthening a coalition of domestic actors that supports the reforms intended by the EU (Knill and Lehmkuhl, 1999, p. 2). This mechanism of Europeanization can be deployed either by market-making or by marketcorrecting policies (Bulmer and Radaelli, 2004, p. 6). In the first case, it is more about policies allowing the entrance of RES into national markets (for example, by removing physical barriers for RES-E such as the connection to the grid). In the second, it is more about improving the competitiveness of RES in the energy markets (for example, by means of financing research and development programmes for RES). The promotion of RES could be considered to be market-correcting as RES are perceived as a means of correcting the negative environmental externalities produced by the EU's energy sector (Knudsen, 2012). Owing to the unfinished liberalization process of the Internal Energy Market (IEM), dominant economic actors within the sector, such as electricity utilities, are also expected to play a key role for the success or failure of policy change regarding RES promotion in the EU (Boasson and Wettestad, 2013, p. 79). Therefore, while the EU renewable energy policy may play an important role in redistributing the power and resources between actor coalitions, the case studies will also analyse the impact of the liberalization of energy markets in the EU on the composition and relative power of the opposing actor coalitions in RES policymaking.

The third mechanism, EU-triggered changes in the beliefs of domestic actors, is the least hierarchical but the most fundamental Europeanization mechanism. This mechanism is about consensus-building, but this time by means of an EU-induced change in the 'cognitive input' of the 
domestic actors (Knill and Lehmkuhl, 2002, p. 262). It might be complementary to the mechanism of altering opportunity structures at the domestic level, since both are oriented towards building support for domestic reforms. By changing the beliefs and expectations of the domestic actors, Europeanization may, for example, overcome persistent institutional veto points at the national level.

For the national case studies, it is crucial to look at the responses of three key actors to developments at the European level: RES producers, environmental non-governmental organizations (ENGOs) and traditional (and often still dominant) corporations and organizations in the sector such as the big electricity utilities. Given the 'packaging' of the EU renewable energy policy as a 'green' policy (Tosun and Solorio, 2011; Morata and Solorio, 2012), it would be expected that for both cases, RES-E and biofuels, the coalition supporting EU reforms should comprise RES producers and ENGOs (Solorio and Popartan, 2014). Such a coalition would be expected to act as a 'change agent', attempting to persuade other domestic actors to become more supportive of the promotion of RES (Börzel and Risse, 2000, p. 9). Conversely, we would expect traditional dominant actors of the sector such as the big electricity utilities to act as veto players against the changes promoted by or through Brussels.

Ideally, Europeanization would lead to the acceptance of the policy in question, leading to a series of policy changes that, in this case, would facilitate a major penetration of RES into the national electricity and transport sectors. In other words, successful Europeanization should lead to some degree of domestic change towards policy models propagated at the EU level (Börzel and Risse, 2000, p. 10). However, there may be cases where Europeanization does not lead to any changes at all, or can even have the paradoxical effect of national policies becoming less European than before (Radaelli, 2000). The first reaction is known as inertia, while the latter is defined as retrenchment, occurring when there is a widely shared negative perception of EU policies (Börzel and Risse, 2000). In this scenario, Europeanization may trigger domestic opposition to the policy in question. Consequently, one of the core concerns of this book and of the individual case studies is to assess whether or not Europeanization has actually led to the desired policy changes at the domestic level.

\subsubsection{Horizontal Europeanization}

Horizontal Europeanization refers to the direct diffusion or transfer of policies from one EU member state to another, within and affected by the 
institutional, political and discursive context of the EU. While bottom-up and top-down Europeanization have been studied for many years, concepts of horizontal Europeanization constitute a more recent strand in the EU literature. Its starting point was an increased scholarly interest in policy areas where the legislative competencies of the EU are limited or where intergovernmental agreement in the Council of Ministers has been difficult or even impossible to achieve. This focus has brought alternative or less direct forms of Europeanization to the front. The EU's Open Method of Coordination (OMC) is the most prominent of these mechanisms of horizontal rather than top-down Europeanization (see, for example, Büchs, 2007; Lodge, 2007; Nedergaard, 2007; Zohlnhöfer and Ostheim, 2007). Although horizontal Europeanization works in the absence of binding supranational law, or in issue areas where the adaptational pressures emanating from the EU are rather limited, it nevertheless may lead to policy change or even to a convergence of domestic policies towards the goals of the EU (Bulmer and Radaelli, 2004). In contrast to the vertical mechanisms of top-down Europeanization, it is based on a decentralized, voluntary and informationbased process of horizontal cross-fertilization of ideas and policies between EU member states. It typically results in a process of voluntary convergence towards common policy goals which may be loosely coordinated by European institutions, as in the case of the OMC, but which may just as well emerge from uncoordinated processes of bilateral imitation and learning between member states.

Being relatively new to the Europeanization literature, the concept of horizontal Europeanization builds on a body of empirical research from comparative politics and international relations which shows that growing economic and political interdependence leads national governments to increasingly orient their domestic policy choices towards the previous choices of other governments. These processes, often labelled as processes of 'policy diffusion', 'horizontal policy learning' or 'policy transfer', have received growing attention in recent years (Jörgens et al., 2014; Busch and Jörgens, 2012a, 2012b; Holzinger et al., 2008; Simmons et al., 2008; Bulmer and Padgett, 2005; Simmons and Elkins, 2004). One of the core findings of this literature is that 'the mutual adjustment of autonomous states to each other's policy decisions' (Busch and Jörgens, 2012a, p. 221) often has effects that are very similar to those of binding international agreements or supranational policymaking through EU directives.

Although a policy diffusion perspective has not yet been systematically incorporated into the study of Europeanization processes, there are some preliminary conceptualizations that our analytical framework can draw 
upon. In a research note published in 2000, Fritz W. Scharpf argued that 'mutual adjustment' between national governments constitutes the 'default mode of Europeanized policy responses to increasing economic interdependence'. 'Here, national governments continue to adopt their own policies nationally, but they do so in response to, or anticipation of, the policy choices of other governments' (Scharpf, 2000, p. 11). Busch and Jörgens (2012b) have substantiated this claim empirically in their study on the diffusion of RES-E policies among EU member states. They find that 'decentralized and voluntary mechanisms of policy coordination can have effects that are very similar to those of centralized policymaking', and argue that processes of top-down Europeanization are often accompanied by less visible processes of bilateral imitation or learning which can best be conceptualized as 'horizontal Europeanization'. In fact, empirical studies show that these processes of decentralized and non-coercive policy diffusion are strongest in 'highly institutionalized contexts like the EU' (Busch and Jörgens, 2012b, p. 81; see also Bulmer and Padgett, 2005). They may occur in the absence of top-down Europeanization, but they may just as well supplement instances of supranational law-making. In the latter case, horizontal Europeanization may manifest itself in a convergence of domestic policies and instruments beyond the concrete goals and measures contained in supranational law.

What are the causal mechanisms underlying processes of policy diffusion? While scholars have identified a large number of potential mechanisms, these can be grouped into three generic categories: (1) (boundedly) rational learning; (2) norm-based imitation; and (3) economic or political competition (Busch and Jörgens, 2012a, pp. 234-235; for a similar categorization see Gilardi, 2012).

Learning occurs when national policymakers search outside national boundaries for effective solutions to domestic problems. The previous policy choices of states which had been confronted with comparable problems may offer valuable clues for their own decisions (Rose, 1991). Especially in complex decision situations, time-pressed policymakers are more likely to adopt policies already carried out somewhere else than to invent completely new programmes (Karch, 2008). Processes of policy learning can be more or less rational. While learning is always based on the belief that the potential benefits of a policy will outweigh its costs Mossberger and Wolman (2003) refer to this as a form of 'prospective policy evaluation' - the information on which the expected costs and benefits of a policy are calculated is often insufficient or biased. Consequently, policy learning usually is at best 'boundedly' rational (Simmons and Elkins, 2003, p. 282; Weyland, 2007). Learning can be expected to 
occur mostly with regard to specific policy instruments, for example with regard to the type of instrument used to promote RES. By observing the effectiveness (but also the negative and/or unintended consequences) of an existing support scheme, policymakers can draw conclusions about the probable performance of this instrument in their own country. This mechanism of learning through prospective policy evaluation constitutes one of the main drivers of horizontal Europeanization.

The second category of mechanisms, norm-based imitation, comprises the different ways in which policy innovations are adopted in order for a country to gain national and international legitimacy. Policy innovations which are highly visible and which represent widely recognized values are particularly suited for symbolic imitation (Braun and Gilardi, 2006). In the area of environmental policy, this mechanism has played a central role, for instance, in the worldwide diffusion of ministries of the environment, but also in the spread of sustainable development strategies and the introduction of constitutional clauses on environmental protection (Busch and Jörgens, 2005; on the diffusion of sustainable development strategies, see also Jörgens, 2004). Norm-based imitation also comprises processes of socialization where certain internationally shared norms of appropriate behaviour serve as role models for domestic policymaking (Finnemore and Sikkink, 1998). This process can be expected to occur mainly with regard to the fundamental decision of whether RES should be promoted at all, but also with regard to the level of national RES targets. Norm diffusion can be strengthened when international organizations or transnational actor networks act as norm entrepreneurs by actively trying to persuade governments to adopt certain policies (Keck and Sikkink, 1998).

The third group comprises several mechanisms based on competition. In the case of economic competition, states adopt policies that are already in place elsewhere, with the strategic aim to preserve or improve their international competitiveness. Mostly this competition is conceived as a race to the bottom, where states alternately lower national standards until a common minimum is reached (Holzinger and Knill, 2005). The most recent national debates about 'excessive' RES promotion being a threat to domestic competitiveness could - in the absence of EU-wide harmonization, that is, top-down Europeanization - eventually lead to a race to the bottom in the form of a cross-national dismantling of RES quotas or Feed-In Tariffs (FITs). A second mechanism in this group is political competition. Here states struggle to become pioneers or early adopters of a policy innovation so that they can influence international policy developments in accordance with their domestic regulatory traditions and 
institutional structures, thereby minimizing future political and economic adjustment costs (Héritier et al., 1996). Often, political regulatory competition triggers action by the EU, leading to legal harmonization based on the policies in place in one or several pioneering member states (bottom-up Europeanization). Thus, the boundaries between the mechanisms of horizontal political competition and bottom-up Europeanization are not always sharp, and their empirical identification depends largely on the outcome; that is, on whether the cross-national leader-follower-laggard dynamics lead to the adoption of policies at the EU-level or not.

In the environmental policy field such processes of diffusion by political competition are found above all in issue areas relevant to the Single European Market (for example, packaging waste laws; see Gehring, 1997; Haverland, 2000). While political competition can be expected to play a role in the early decisions of EU member states to adopt RES policies in the first place, economic competition should occur primarily in times of economic crisis, especially when some forerunners have unilaterally introduced ambitious domestic policies, but attempts of an EU-wide harmonization of these policies have failed.

From the different ways in which horizontal Europeanization may occur in EU renewable energy policy, one seems particularly probable. We expect horizontal Europeanization in the EU renewable energy policy to occur primarily with regard to the design of support schemes. Since the negotiations of the first RES-E directive, the Commission has been pursuing the goal of having a European support scheme for RES-E in line with market-based mechanisms (see Chapter 2 by Solorio and Bocquillon). But (as shown in more detail in Chapter 2) this has been a history of failures for the Commission. The attempt at having a European support scheme was frustrated both during the negotiations of 2001 and again during the discussions of the renewable energy directive (RED) in 2009. In order to compensate for the lack of a European support scheme, the Commission set up a model close to the OMC. As a result, EU renewable energy policy facilitates the conditions for a horizontal Europeanization (Kahles and Müller, 2013). This function has been reinforced with the elaboration of national renewable energy action plans, intended to trigger an information-based process of cross-fertilization of ideas and policies between EU member states. Against this backdrop, Busch and Jörgens (2012b) as well as Jacobs (2012) explain the rapid spread of national FITs among EU member states despite the EU's inability to agree on a specific support scheme as a typical case of horizontal Europeanization. While the biofuels case has not experienced a similar debate on the harmonization of support schemes, it certainly also 
presents opportunities for analysing the diffusion of support schemes as a process of horizontal Europeanization. An example would be the diffusion of tax exemptions as a mechanism for biofuels promotion among EU member states (Wiesenthal et al., 2009, p. 794). Nevertheless, horizontal Europeanization can also be expected to occur with regard to RES targets (norm-based imitation) and, more recently, with regard to the lowering or dismantling of FITs or RES quotas.

\subsection{OUTLINE OF THE BOOK}

This book brings together experts from several European countries in an attempt to provide detailed and differentiated insights on the EU renewable energy policy, how it evolved, and its interaction with the domestic policies of its member states (and even beyond the EU). Although all contributors have been invited to adopt the overall analytical framework presented in the previous section, they have also been encouraged to reinforce it with the most suitable theoretical and analytical tools for their respective chapters.

In Chapter 2, Israel Solorio and Pierre Bocquillon trace the chronological evolution of the European structures of governance for RES promotion, including both the RES-E and the RES for transport (RES-T) sectors. By focusing on the historical evolution of the EU renewable energy policy, the authors capture the tensions between the attempts at centralizing renewable energy governance at the EU level (that is, Europeanization), and the preferences of several member states pushing for the renationalization of this policy.

In Chapter 3, Thomas Vogelpohl, Dörte Ohlhorst, Mischa Bechberger and Bernd Hirschl open the series of national case studies by examining the case of Germany as a pioneer in RES promotion. They expound the way in which Germany's interaction with the EU and other member states shows traits of all three types of Europeanization (top-down, bottom-up and horizontal). Importantly, the authors of this case study analyse how the German pioneer role - including its 'Energiewende' has not always been welcomed in Europe and has sometimes led to conflict and disputes at the European level.

Chapter 4 tests the long-standing perception of the Netherlands as a 'green' member state. By assessing the Dutch behaviour in the context of the EU renewable energy policy and the influence of Europeanization processes - and contrary to what might have been expected from this environmental forerunner - Thomas Hoppe and Ellen van Bueren show that the Netherlands has adopted a laggard role when it comes to RES 
promotion. Continuing with the cases of 'green' member states, in Chapter 5 Helene Dyrhauge explains Denmark's role as an environmental forerunner by tracking the development of the national energy policy and its influence on EU renewable energy policy (that is, bottom-up Europeanization).

Chapter 6 deals with a very special national case: the United Kingdom (UK). In this chapter, Israel Solorio and Jenny Fairbrass provide an in-depth analysis of the British policy-shaping capacity at the EU level. The authors demonstrate that, in spite of the Brexit debates, the UK has been a key actor in the construction of EU renewable energy policy by means of both bottom-up and horizontal Europeanization, while the national energy policy has been only marginally transformed by European integration.

Chapter 7 tackles the Italian case and its relationship with the EU renewable energy policy. With it, Maria Rosaria Di Nucci and Daniele Russolillo open the series of national case studies dealing with Southern European countries. The authors argue that Italy has neither been influential at the EU level, nor has it complied effectively and in a timely manner with EU policies and institutional pressures. In Chapter 8, Israel Solorio and Rosa Fernandez argue that, beyond the economic cycle, the explanation of the early expansion as well as the recent retrenchment of the Spanish renewable energy policy importantly lies in the interaction between European factors and the domestic scenario. To complement the perspective on the Southern European countries' role, Chapter 9 by Pierre Bocquillon and Aurélien Evrard focuses on the French case. The authors illustrate the limited influence of the European factors in the development of French renewable energy policy and the ambiguous attitude of France at the European level.

The case of Poland is addressed in Chapter 10 by Karolina Jankowska and Andrzej Ancygier, opening the set of case studies dedicated to Eastern European countries. Given that the Polish government has resisted any progress in the European renewable energy policy that could potentially require or cause far-reaching changes to the national status quo (bottom-up Europeanization), this case study is also key for understanding the evolution of the EU renewable energy policy. In Chapter 11, Simona Davidescu shows that the need to adopt the EU acquis provided Romania with both an impetus and a straitjacket for reform in the RES sector, resulting in uneven development across the RES-E and biofuels sectors and a variety of structural, procedural and practical barriers to policy implementation. Chapter 12 by Ralitsa Hiteva and Tomas Maltby presents the case study of Bulgaria, a country where the implementation of EU renewable energy policy (that is top-down Europeanization) has 
been affected by lack of administrative capacity to govern a transition towards a larger share of RES.

In Chapter 13, Gonzalo Escribano tackles Europeanization from a different perspective. He develops the concept of outward Europeanization for referring to the EU efforts to promote RES-E related norms in the neighbourhood and tests it against the development of the Mediterranean Solar Plan in Morocco. Complementing this focus on the external dimension of the EU renewable energy policy, Lorenzo Di Lucia examines in Chapter 14 the external dimension of the EU biofuels policy and its impact in Mozambique. In the closing chapter, Helge Jörgens, Eva Öller and Israel Solorio outline the key findings of the case studies and analyse them in light of the three-sided Europeanization analytical framework presented above.

\section{NOTE}

1. In the field of biofuels, it is important to distinguish between first-generation biofuels, which are produced from food crops such as starch, sugar, animal fats and vegetable oil, and second-generation biofuels, which can be manufactured from various types of biomass including, for example, organic waste.

\section{REFERENCES}

Andersen, M.S. and D. Liefferink (1997), European Environmental Policy: The Pioneers, Manchester: Manchester University Press.

Bache, I and A. Jordan (2006), The Europeanization of British Politics, London: Palgrave Macmillan.

Barnes, P. (2013), 'The changing fortunes of nuclear energy in the sustainability discourse', in P. Barnes and T. Hoerber (eds), Sustainable Development and Governance in Europe: The Evolution of the Discourse on Sustainability, Abingdon and New York: Routledge, pp. 106-120.

Boasson, E.L. and J. Wettestad (2013), EU Climate Policy: Industry, Policy Interaction and External Environment, Farnham and Burlington, VT: Ashgate.

Bomberg, E. and J. Peterson (2000), 'Policy transfer and Europeanization: passing the Heineken test?', Queens Papers on Europeanization, No. 2.

Börzel, T. (2000), 'Why there is no southern problem: on environmental leaders and laggards in the European Union', Journal of European Public Policy, 7 (1), 141-162.

Börzel, T. (2002), 'Member State responses to Europeanization', Journal of Common Market Studies, 40 (2), 193-214.

Börzel, T. and T. Risse (2000), 'When Europe hits home: Europeanization and domestic change', European Integration online Papers (EIoP), 4 (15), http:// eiop.or.at/eiop/pdf/2000-015.pdf. 
Braun, D. and F. Gilardi (2006), 'Taking “Galton's problem” seriously: towards a theory of policy diffusion', Journal of Theoretical Politics, 18 (3), 298-322.

Buchan, D. (2009), Energy and Climate Change: Europe at the Crossroads, Oxford: Oxford University Press / Oxford Institute for Energy Studies.

Büchs, M. (2007), New Governance in European Social Policy: The Open Method of Coordination, Basingstoke: Palgrave Macmillan.

Bulmer, S. and S. Padgett (2005), 'Policy transfer in the European Union: an institutionalist perspective', British Journal of Political Science, 35 (1), $103-126$.

Bulmer S. and C. Radaelli (2004), 'The Europeanisation of national policy?', Queen's Papers on Europeanisation, No. 1/2004.

Busch, P.-O. and H. Jörgens (2005), 'International patterns of environmental policy change and convergence', European Environment, 15 (2), 80-101.

Busch, P.-O. and H. Jörgens (2012a), 'Governance by diffusion: exploring a new mechanism of international policy coordination', in J. Meadowcroft, O. Langhelle and A. Ruud (eds), Governance, Democracy and Sustainable Development: Moving Beyond the Impasse?, Cheltenham and Northampton, MA: Edward Elgar Publishing, pp. 221-248.

Busch, P.-O. and H. Jörgens (2012b), 'Europeanization through diffusion? Renewable energy policies and alternative sources for European convergence', in F. Morata and I. Solorio (eds), European Energy Policy: An Environmental Approach, Cheltenham and Northampton, MA: Edward Elgar Publishing, pp. 66-84.

Caporaso, J. (2007), 'The three worlds of regional integration theory', in P. Graziano and M.P. Vink (eds), Europeanization: New Research Agendas, New York: Palgrave Macmillan, pp. 23-34.

Finnemore, M. and K. Sikkink (1998), 'International norm dynamics and political change', International Organization, 52 (4), 887-917.

Gehring, T. (1997), 'Governing in nested institutions: environmental policy in the European Union and the case of packaging waste', Journal of European Public Policy, 4 (3), 337-354.

Gilardi, F. (2012), 'Transnational diffusion: norms, ideas, and policies', in W. Carlsnaes, T. Risse and B.A. Simmons (eds), Handbook of International Relations, London: Sage, pp. 453-477.

Haverland, M. (2000), 'National adaptation to European integration: the importance of institutional veto points', Journal of Public Policy, 20 (1), 83-103.

Héritier, A., C. Knill and S. Mingers (1996), Ringing the Changes in Europe: Regulatory Competition and the Transformation of the State, Berlin: De Gruyter.

Holzinger, K., H. Jörgens and C. Knill (2008), 'State of the art - conceptualizing environmental policy convergence', in K. Holzinger, C. Knill and B. Arts (eds), Environmental Policy Convergence in Europe: The Impact of International Institutions and Trade, Cambridge: Cambridge University Press, pp. 7-29.

Holzinger, K. and C. Knill (2005), 'Causes and conditions of cross-national policy convergence'. Journal of European Public Policy, 12 (5), 775-796.

Jacobs, D. (2012), Renewable Energy Policy Convergence in the EU, Farnham: Ashgate. 
Jörgens, H. (2004), 'Governance by diffusion - implementing global norms through cross-national imitation and learning', in W.M. Lafferty (ed.), Governance for Sustainable Development: The Challenge of Adapting Form to Function, Cheltenham and Northampton, MA: Edward Elgar Publishing, pp. 246-283.

Jörgens, H., A. Lenschow and D. Liefferink (eds) (2014), Understanding Environmental Policy Convergence: The Power of Words, Rules and Money, Cambridge: Cambridge University Press.

Kahles, M. and T. Müller (2013), 'Powerful national support systems versus Europe-wide harmonisation - assessment of competing and converging support instruments', in R. Hinrichs-Rahlwes (ed.), Sustainable Energy Policies for Europe: Towards 100\% Renewable Energy, London: Routledge, pp. 69-79.

Karch, A. (2008), 'Diffusion mechanisms and the policymaking process', paper prepared for presentation at the 2008 Annual Meeting of the American Political Science Association, Boston, MA, 28-31 August.

Keck, M.E. and K. Sikkink (1998), Activists Beyond Borders: Advocacy Networks in International Politics, Ithaca, NY: Cornell University Press.

Knill C. and D. Lehmkuhl (1999), 'How Europe matters: different mechanisms of Europeanization', European Integration online Papers (EIoP), 3 (7), http://eiop.or.at/eiop/texte/1999-007a.htm.

Knill, C. and D. Lehmkuhl (2002), 'The national impact of European Union regulatory policy: three Europeanization mechanisms', European Journal of Political Research, 41, 255-280.

Knudsen, J. (2012), 'Renewable energy and environmental policy integration: renewable fuel for the European energy policy?', in F. Morata and I. Solorio (eds), European Energy Policy: An Environmental Approach, Cheltenham and Northampton, MA: Edward Elgar Publishing, pp. 48-65.

Lenschow, A. and C. Sprungk (2010), 'The myth of a green Europe', JCMS: Journal of Common Market Studies, 48, 133-154.

Liefferink, D. and M.S. Andersen (1998), 'Strategies of the green member states in EU environmental policy-making', Journal of European Public Policy, 5 (2), 254-270.

Liefferink, D. and A. Jordan (2004), 'Europeanization and policy convergence: a basis for comparative analysis', in A. Jordan and D. Liefferink (eds), Environmental Policy in Europe: The Europeanization of National Environmental Policy, London: Routledge, pp. 14-28.

Lodge, M. (2007), 'Comparing non-hierarchical governance in action: the Open Method of Coordination in pensions and information society', Journal of Common Market Studies, 45 (2), 343-365.

Matláry, J. (1997), Energy Policy in the European Union, New York: St Martin's Press.

Mez, L. (ed.) (2007), Green Power Markets: Support Schemes, Case Studies and Perspectives, Brentwood: Multi-Science Publishing.

Morata, F. and I. Solorio (eds) (2012), European Energy Policy: An Environmental Approach, Cheltenham and Northampton, MA: Edward Elgar Publishing. 
Mossberger, K. and H. Wolman (2003), 'Policy transfer as a form of prospective policy evaluation: challenges and recommendations', Public Administration Review, 63 (4), 428-440.

Nedergaard, P. (2007), 'Maximizing policy learning in international committees: an analysis of the European Open Method of Coordination (OMC) committees', Scandinavian Political Studies, 30 (4), 521-546.

Radaelli, C.M. (2000), 'Whither Europeanization? Concept stretching and substantive change'. European Integration online Papers (EIoP), 4 (8), http:// www.eiop.or.at/eiop/pdf/2000-008.pdf.

Radaelli, C.M. (2004), 'Europeanisation: solution or problem?'. European Integration online Papers (EIoP), 8 (16), http://www.eiop.or.at/eiop/pdf/2004016.pdf.

Risse, T., M.G. Cowles and J. Caporaso (2001), 'Europeanization and domestic change: introduction', in M.G. Cowles, J. Caporaso and T. Risse (eds), Transforming Europe: Europeanization and Domestic Change, Ithaca, NY: Cornell University Press, pp. 1-20.

Rose, R. (1991), 'What is lesson-drawing?', Journal of Public Policy, 11 (1), $3-30$.

Scharpf, F.W. (2000), 'Notes toward a theory of multilevel governing in Europe', Discussion Paper 00/05, Cologne: MPIfG.

Simmons, B.A., F. Dobbin and G. Garrett (eds) (2008), The Global Diffusion of Markets and Democracy, Cambridge: Cambridge University Press.

Simmons, B.A. and Z. Elkins (2003), 'Globalization and policy diffusion: explaining three decades of liberalization', in M. Kahler and D.A. Lake (eds), Governance in a Global Economy: Political Authority in Transition, Princeton, NJ: Princeton University Press, pp. 275-304.

Simmons, B.A. and Z. Elkins (2004), 'The globalization of liberalization: policy diffusion in the international political economy', American Political Science Review, 98 (1), 171-189.

Solorio, I. and L. Popartan (2014), 'The implementation of the EU biofuels policy in Spain and the UK: a case of contested Europeanization', Biofuels, 5 (2), 129-140.

Tosun, J., S. Biesenbender and K. Schulze (eds) (2015), Energy Policy Making in the EU: Building the Agenda, London: Springer.

Tosun, J. and I. Solorio (2011), 'Exploring the energy-environment relationship in the EU: perspectives and challenges for theorizing and empirical analysis', in J. Tosun and I. Solorio (eds), Energy and Environment in Europe: Assessing a Complex Relationship, European Integration online Papers (EIoP), Special Mini-Issue 1, Vol. 15, http://eiop.or.at/eiop/pdf/2011-007.pdf.

Vink, M.P. and P. Graziano (2007), 'Challenges of a new research agenda', in P. Graziano and M.P. Vink (eds), Europeanization: New Research Agendas, Basingstoke: Palgrave, pp. 3-20.

Weyland, K. (2007), Bounded Rationality and Policy Diffusion: Social Sector Reform in Latin America, Princeton, NJ: Princeton University Press.

Wiesenthal T., G. Leduc, P. Christidis, B. Schade, L. Pelkmans, L. Govaerts and P. Georgepoulos (2009), 'Biofuel support policies in Europe: lessons learnt for the long way ahead', Renewable and Sustainable Energy Reviews, 13 (4), 789-800. 
Wurzel, R.K.W. and J. Connelly (eds) (2011), The European Union as a Leader in International Climate Change Politics, Abingdon: Routledge.

Zohlnhöfer, R. and T. Ostheim (2007), 'Politiktransfer durch die Europäische Beschäftigungspolitik? Methodische Überlegungen und empirische Analyse des Falls Deutschland', in K. Holzinger, H. Jörgens and C. Knill (eds), Transfer, Diffusion und Konvergenz von Politiken, Wiesbaden: VS Verlag für Sozialwissenschaften, pp. 327-347. 